\title{
ビードフラッシュ法による溶接残留応力の逆問題解析* (厚さ方向の固有ひずみ分布を考慮した解法の提案)
}

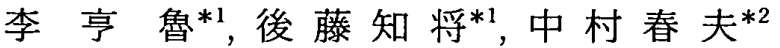

\begin{abstract}
Inverse Analysis of Welding Residual Stresses by the Bead Flush Method (Consideration of Eigenstrain Distribution in the Thickness Direction)
\end{abstract}

\author{
Hyoungno LEE, Tomomasa GOTO and Haruo NAKAMURA*3 \\ ${ }^{* 3}$ Department of Mechanical and Environmental Informatics, Tokyo Institute of Technology, \\ 2-12-1 O-okayama, Meguro-ku, Tokyo, 152-8552 Japan
}

\begin{abstract}
Nondestructive evaluation of welding residual stresses is required to assess the structural integrity of engineering components. Authors have proposed a new nondestructive evaluation method called "the Bead Flush Method" for welding residual stress evaluation. Up to the present studies, the solution set of eigenstrains in the bead flush method has been determined under the assumption which eigenstrain distributions of the bead and the thickness directions are constant, but in general, except for relatively quite thin plates, this assumption does not come into existent. For wider applicability of the bead flush method, the conventional procedure should be improved. In this study, we propose a new evaluation algorism of welding residual stresses applicable to thicker welded plates. Its main characteristic is to enforce eigenstrain determination process in inverse analysis. To do this, a new eigenstrain function based on welding simulations and the optimization method of its parameters using response surface methodology are proposed. And also its utility is confirmed by simulations of the bead flush method.
\end{abstract}

Key Words: Welding Residual Stress, Eigenstrain, The Bead Flush Method, Inverse Analysis, FEM, Surface Response Methodology, Nondestructive Evaluation

\section{1. 楮覦}

大型溶接構造物では, 溶接部の残留応力が応力 腐食割れなどの損傷の発生, 進展に大きな影響を及 ぼす可能性があるので, 稼動中の溶接構造物の健全 性や余寿命を評価する際には, 溶接残留応力の非破 壊的な測定が重要な課題となる。従来から, 溶接 残留応力の非破壊測定手法として一般に用いられて いるX 線法は, 部材内部（たとえば, 配管の内表 面）の応力が測定できない. 最近では, 内部応力測 定手法として中性子回折法"が注目されているが, 装置の規模が極めて大きく現場向きではない.

そこで, 溶接残留応力の新しい非破壊測定手法 として，著者らは溶接ビードの余盛りを除去する際 に構造物表面に生じるひずみ変化から，逆問題解析 により固有ひずみを推定して，それをもとに順問題 解析を行うことより溶接残留応力を評価するという, 解析援用型の “ビードフラッシュ法”ーを提案し てきた. 余盛り止端は応力集中源を形成し，本来除

* 原稿受付 2002 年 1 月 18 日.

*1 正員, 東京工業大学大学院博士課程 ( $152-8552$ 東京都目 黒区大岡山 2-12-1).

*2 正員, 東京工業大学大学院情報理工学研究科.

E-mail : hnakamur@mei.titech.ac.jp
去することが望ましいが，経済的な理由により除去 されていない，したがって，余盛りを除去するとい う本手法は本質的に非破壊的な手法である。本手法 の特徵は，（1）部材全領域の残留応力が評価でき る可能性がある，（2）純粋な溶接シミュレーショ ンと異なり，実証性を有する，（3）残留応力は有 限要素解析 (FEM) によりえられるので，その解析 解を初期応力として直接強度解析が実施できる,

（4）溶接止端などの局所応力が正確に評価できる,

（5）必要な材料定数は室温における弾性係数のみ

であり（降伏応力や熱膨張係数の温度依存性は不 要），母材，熱影響部，溶接金属などの微視組織の 相違を考慮する必要がない，などなどである.

これまでの研究いーゅでは，逆問題解析による固有 ひずみの推定に際して，固有ひずみが溶接部材の厚 さ方向や溶接線方向には変化せず，溶接線に垂直な 長手方向にのみ変化すると仮定してきた. しかし， この仮定は薄板で単一の溶接パスの場合にしか成立 しない.

そこで本研究では，本手法を厚板・マルチパス溶 接に㹡張するために，固有ひずみが板厚方向にも分布 する場合について，その解析手法の提案およびその有 効性評価を行う. 


\section{2. ビードフラッシュ法}

\section{1 ビードフラッシュ法の原理め}

物体に固有ひずみが付与されると，その物体は応 力が平衡状態となるように変形し，内部に弾性ひずみ

（残留応力）を生じる.この平衡状態は，固有ひずみ 分布が既知であれば，固有ひずみを初期ひずみとする 弾性有限要素解析によって簡単に求めることができる. すなわち，物体に残留している固有ひずみ分布を何ら かの方法で推定することができれば，数值解析によっ て物体に生じる 3 次元残留応力分布を求めることがで きる.

図 1 にビードフラッシュ法の概念図を示す，残留 応力は溶接部近傍の固有ひずみ（熱ひずみ，塑性ひず み，変態ひずみなど）により生じる. 溶接部には余盛 りと呼ばれる，盛り上がった部分が存在する. 余盛り を除去してその部分の固有ひずみを除去すると，部材 の幾何学的境界条件と力学的境界条件（固有ひずみの 存在領域）か変化するために残留応力の再配分が生じ, それに伴って微小な弾性ひずみが解放される.

本手法ではまず，部材表面の溶接線近傍に貼付し たひずみゲージにより，余盛り除去に伴って解放され る弾性ひずみを測定する. 次に，測定した解放ひずみ から逆問題解析により固有ひずみ分布を推定する. 最 後に，固有ひずみ分布の推定結果を基に，「弾性」 FEM解析により残留応力分布を評価する.

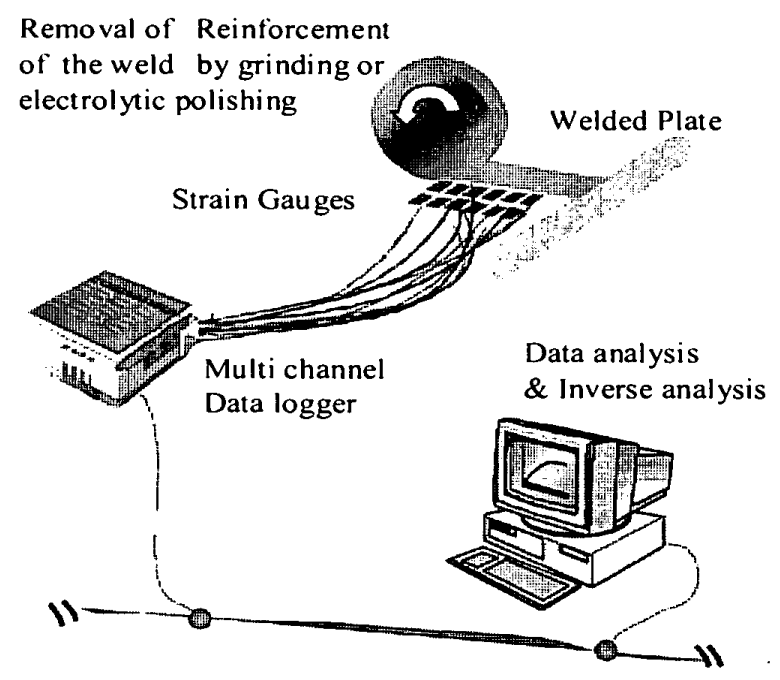

Fig.1 The concept of the Bead Flush Method

\section{2 ビードフラッシュ法の定式化}

具体的な方法を以下に示す. 固有ひずみ分布 $\left\{\varepsilon^{*}\right\}$ 之弾性ひずみ分布 $\left\{\varepsilon^{e}\right\}$ の間には次式が成り立つ.

$$
\left\{\varepsilon^{e}\right\}=[H]\left\{\varepsilon^{*}\right\}+\{e r r\}
$$

ここで, lerhは測定誤差 そして[月は弾性応答マト リックス（3n次の正方マトリックス, $n$ は総要素数 である.

FEM 解析において余盛り除去前後の弾性応答マトリ クスを $\left[H_{b}\right],\left[H_{a}\right]$ とすれば その差 $\left[H_{h a}\right]$ は次式で 表される (余盛り除去は余盛りの剛性をゼロにするこ とで達成できる。

$$
\left[H_{h a}\right]=\left[H_{a}\right]-\left[H_{b}\right]
$$

さらに，余盛り除去の際に新たな塑性変形を与え ない限り固有ひずみ分布は不変 $\left(\left|\varepsilon^{*}\right|=\left|\varepsilon^{*}\right|=\left|\varepsilon^{*}\right|\right)$ で あるとみなすことができるため，余盛り除去に伴って 生じる弾性ひずみ変化 $|\Delta \varepsilon|$ は以下のように表すこと ができる.

$$
\begin{aligned}
& \{\Delta \varepsilon\}=\left\{\varepsilon_{a}\right\}-\left\{\varepsilon_{b}\right\} \\
& =\left[H_{a}\right]\left\{\varepsilon^{*}{ }_{a}\right\}-\left[H_{b}\right]\left\{\varepsilon^{*}{ }_{b}\right\} \\
& =\left(\left[H_{a}\right]-\left[H_{b}\right]\right)\left\{\varepsilon^{*}\right\}=\left[H_{h a}\right]\left\{\varepsilon^{*}\right\}
\end{aligned}
$$

そこで，部材表面で m個の解放ひずみ し，さらに $\left[H_{h}\right]$ の中から，解放ひずみ測定点に対応す る行のみを取り出した部分マトリクス $\left.{ }_{\mathrm{d}} H_{h}\right]$ を用いる と. 式(3) は次式のようになる.

$$
\left\{_{m} \Delta \varepsilon\right\}=\left[{ }_{m} H_{b a}\right]\left\{\varepsilon^{*}\right\}
$$

したがって，固有ひずみは最小二乗法により次式とし て求めることができる.

$$
\begin{aligned}
& \left.\left\{\varepsilon^{*}\right\}=\left[{ }_{m} H_{b a}\right]^{-}{ }_{m} \Delta \varepsilon\right\} \\
& \text { ただし, } \left.\left.{ }_{{ }_{m}} H_{b a}\right]^{-} \text {は }{ }_{m} H_{b a}\right]
\end{aligned}
$$
ある.

\section{3. 板厚方向に $\left\{\varepsilon^{*}\right\}$ が分布する埼合への拡張}

溶接固有ひずみの分布形状に関しては，これまで いくつかの研究がなされてきている"1110.しかし，そ れらはいずれも順問題解析を前提とした研究である. ビードフラッシュ法の場合, 逆問題解析はいわゆる悪 条件問題となり，固有ひずみの分布の決定に際しては， 評価する分布関数形状に先見情報を予め導入して, 解 空間の限定を行うなど, 逆問題特有の工夫が必要であ る. そこで, 以下では固有ひずみ解のおおよその分布 形状を溶接の熱弾塑性シミュレーションで推定して, 
その結果を解空間の限定に用いるという, 新しい解析 援用型の手法の提案を行う. よく知られているように, 熱弾塑性シミュレーションに際しては，溶接条件のほ かに母材や溶接金属の降伏沁力ならびに熱膨張係数の 温度依存性など正確な材料定数が必要とされるが，そ れらを正確に評価して残留応力を評価することはかな り困難である. 一方, 本手法は, 残留応力ではなく固 有ひずみの分布形状の概形をシミュレーションで求め, 正確な分布は実験結果に基づき決定するという，実証 性を有するという点に, その特徵がある.

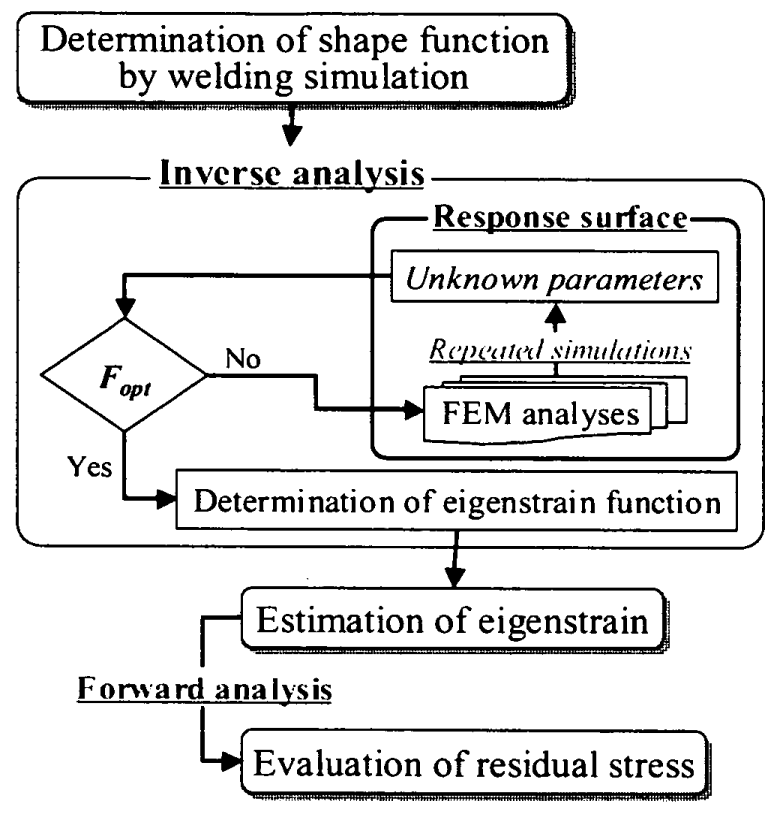

Fig2 The proposed algorism to improve the accuracy of the bead flush method

\section{1 解析援用型残留応力評洒手順}

固有ひずみが板厚方向にも分布する厚板の場合を 対象として，ビードフラッシュ法の新しい評価手順の 概念図を図 2 に示寸. まず, 溶接シミュレーションを実施し て, 固有ひずみの概形と分布する範囲を求める. それ をもとに，固有ひずみの仮の形状関数を決定する.こ の形状関数を用いて, 計算機上でビードフラッシュ法 のシミュレーション，すなわち余盛りを計算機上で削 除して，弾性解放ひずみを求め，それをもとに逆問題 解析を行い，関数形の妥当性を調べ，最適な関数形を 決定する. 関数形の決定手順に関しては，これまでの 薄板の手法" "がそのまま踏襲できる．ただし，後述 するように厚板の場合には，式(5)が非線形となるため, 繰り返し計算が必要となり，しかも繰り返しループの なかに FEM 解析が含まれる. そこで, 繰り返しル プの FEM 計算を応答曲面法"をを用いることにより省 略する．応答曲面法は，少ない計算により小さい分散
の変数一応答間の近似関係式を得るために用いられる 手法であり，具体的な手順は後述する.

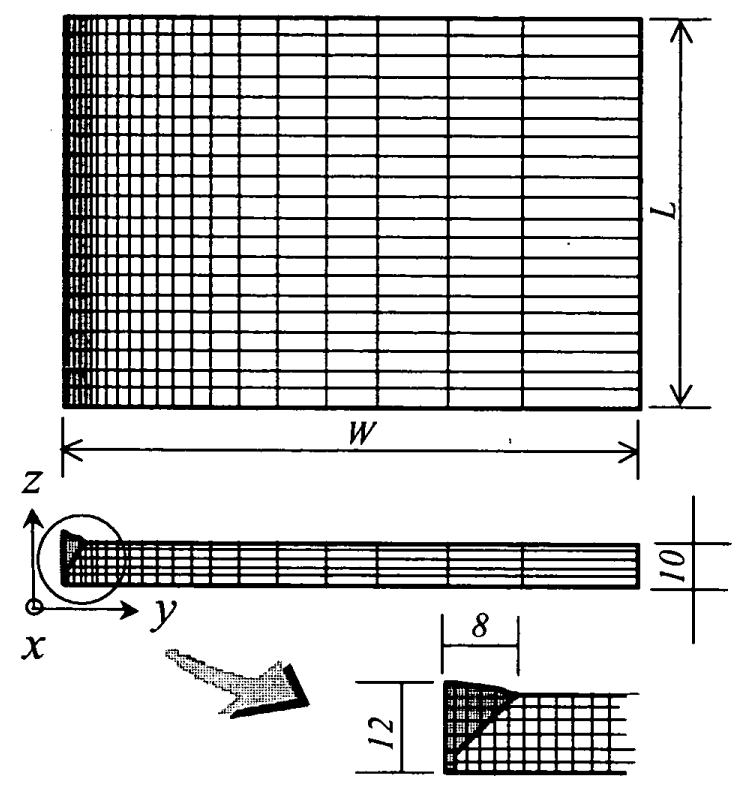

Fig.3 The FEM model of a buttwelded plate

\section{2 固有ひずみ閒数形の決定と解析方法}

従来のビードフラッシュ法"では，板厚方向の固 有ひずみが一定であるという仮定に基づいて補足情報 を導入し, 式(6)に示す Logistic 関数を用いて固有ひ ずみ分布を求めた.

$$
\varepsilon^{*}(y)=\sum_{i=1}^{4} \frac{A_{s i}}{1+\exp \left(p+q_{i} y\right)}
$$

ただし, $p$ と $q_{i}$ は定数 $\left(p=5, q_{F}=025, q_{z}=03, q_{7}=0.4, q_{\tau}=0.6\right)$ ， $A_{s i}$ は未知定数である. 式 (6) は単純な多項式表示と比 較して，より少ない未知パラメータで固有ひずみ分布 が表示でき，かつ，逆問題解析において，解の振動を 相対的に抑制することが可能である゙. しかし，厚板 の場合における分布形状は未知である. そこで, 以下 では分布形を決定するために，V 型開先の笑合せ溶接 平板を例にとり，具体的な分布形状決定の概念を示す. まず, 溶接平板の溶接シミュレーションを行い，固有 ひずみの仮の形状関数(これは今回仮定している後述の 式(7)以外でもかまわない)求める. 次に，その形状 関数を用いてビードフラッシュ法により解析を行う.

図 3 にビードフラッシュ法の FEM 解析モデルを示す. 溶接平板の寸法は $100 \mathrm{~mm} \times 200 \mathrm{~mm} \times 10 \mathrm{~mm}(L \times$ 收 $\times d$ ，余盛 り高さは $2 \pi \mathrm{mm}$ 総要素数は 3680 個，総接点数は 4641 個 である，材料物性値はステンレス鋼を想定し，縦弾性 係数 $E=2.0 \times 10^{5} \mathrm{MPa}$ ポアソン比 $v=0.3$ とした 解析は溶接平板の $1 / 4$ を対象として 汎 F⿵M プログラ 
ムANSYS 5.7 を用いて行った

本手法では，固有ひずみの推定は式（6）あるいは 後述する式（7）に基づき行う. したがって，モデル に負荷する力学的境界条件も, 式 (6) あるいは後述 する式 (7) に基づき与えてしまうと, 推定結果が正 解に一致する可能性が高くなると考えられる. そこで, 力学的境界条件は, 後述する上田らの近似式 (11) を用 い，そのパラメータを種々に変化させて，さまざまな 溶接条件を再現した.

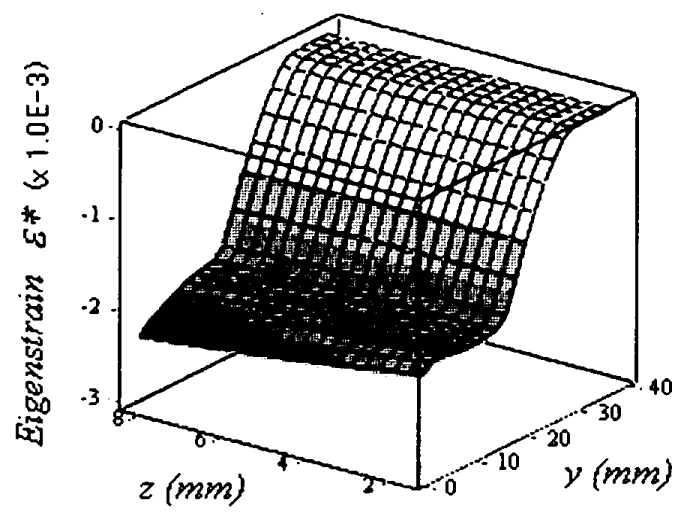

(a) Eigenstrain distribution $\varepsilon_{x}^{*}$ by welding simulation

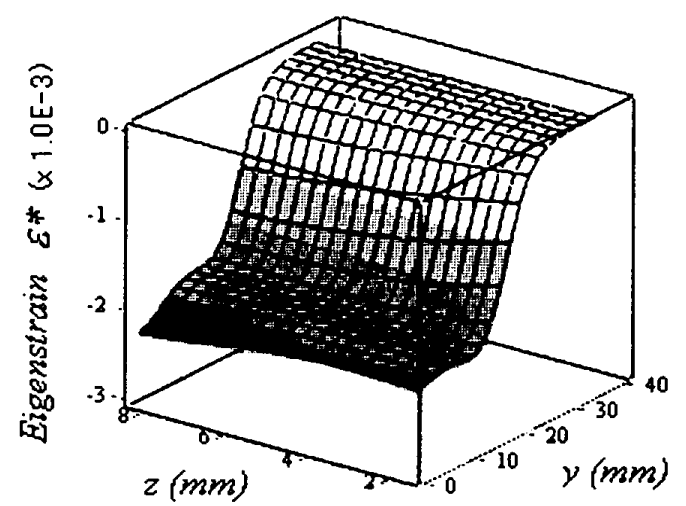

(b) Fitted eigenstrain distribution $\varepsilon_{x}^{*}$ by Eq.(7)

Fig. 4 Comparison of eigenstrain distributions by the welding simulation and fitted one by Eq.(7)

一例として, 板厚 $10 \mathrm{~mm}$ で $\mathrm{V}$ 型開先, 溶接パス $2 の$ 溶接平板の場合を取り上げ, 固有ひずみの形状関数を 決める手順を以下に具体的に示す．まず，溶接シミュ レーション(熱弾塑性解析) を実施した. 図 4 (a)に固 有ひずみの $x$ 成分 $\varepsilon_{1}^{\prime}$ の分布を示す. 溶接過程にお ける温度分布は板幅 (y)方向と板厚( 引方向に対して。 最終パスを中心とする棈円状の形状をしていた．そ こで，固有ひずみ分布の等高線を図 5 のような棈円
状と仮定する. この棈円の $y$ 方向に対する $z$ 方向の 半径比を板厚パラメータ $\alpha$ と定義すると, 仮定した 固有ひずみ関数は式(7)のように変換できる.

$$
\begin{gathered}
\varepsilon_{*}^{*}(y, z)=\sum_{i=1}^{4}\left(\frac{A_{s i}}{1+\exp \left(p+q_{i} \sqrt{y^{2}+z^{2} / \alpha^{2}}\right)}\right) \\
(s=x, y, \lambda)
\end{gathered}
$$

ここで， $A_{s i}$ と $\alpha$ は末知定数である. $\alpha$ が無限大なら ば $\varepsilon_{s}^{*}(y, わ$ は厚さ方向には一定で, 逆にゼロに近づ くほど厚さ方向の勾配が大きくなる. 図 4 (b) に式 (7)を用いて図4 (a) の結果を最小二乗法により回帰し た結果を示す. ただし，このときの式 (7)の板厚パラ

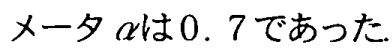

図4 (b) は図4(a) と良く一致しており，式(クで提 案した固有ひずみ関数により，厚板の固有ひずみ分布 がよく表現されていることが分かる．式わでは， $p$ と $q_{i}$ として薄板の值"を用いた. ただし、図4(a)の 結果に基づき，計算機により余盛り除去シミュレーシ ヨンを行い，部材表面で測定される解放ひずみを用い て計算機上で $p$ と $q_{i}$ を系統的に変化させるビードフ ラッシュ法を実行し，解の精度を比較することにより， $p$ と $q_{i}$ の最適化を容易に行うことができる.

実際の固有ひずみ分布は溶接緒条件や幾何学的条 件などにより当然異なる．上田 (I) 固有ひずみ分布を 図 5 の r方向に関しては, HAZ 部までは線形関数を, その外部では指数関数を用いて近似している. そこ で，本研究ではその関数形を用いて正解の固有ひず み分布をモデルに与え，式（6）あるいは式（7）の Logistic 関数形により残留応力の推定を行った.

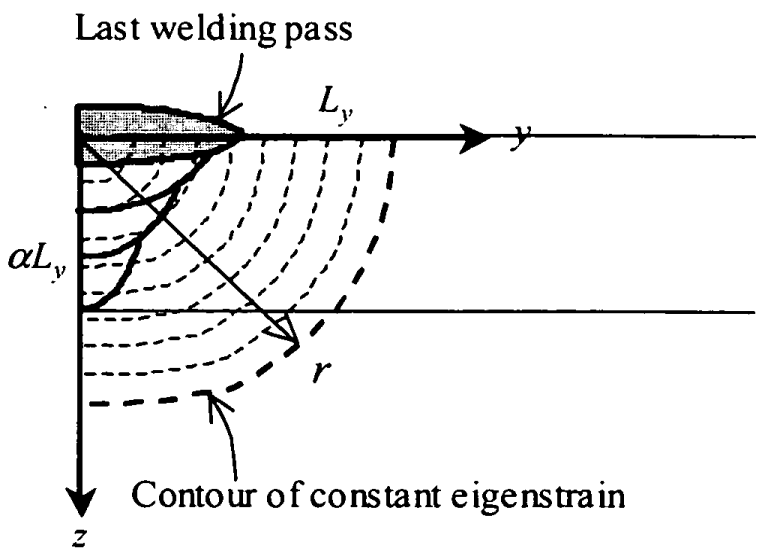

Fig. 5 The schematic shape of the eigenstrain distribution near a weld 


\section{3 板原方向パラメータ $\alpha$ の最通化}

以下では正解の固有ひずみを負荷したモデル対し て，式(7)を用いて $\alpha$ の最適近似值を求める方法につい て説明する.

まず， 正解の固有ひずみを図 3 のモデルに負荷し てシミュレーションにより余盛り除去を行い，弾性解 放ひずみを求める. 次に, 式(1)のように弾性解放ひ ずみ及び各 $\alpha$ にる応答行列を代入して，式(8)を求 める.

$$
\left\{_{m} \Delta \varepsilon\right\}=[H(\alpha)]\left\{\varepsilon^{*}\right\}+\{e r r\}
$$

ここで，誤差 lerhの二乗和を評価関数 と と定義する と, $\alpha$ の最適近似值 $\alpha_{I m !}$ は，次式のように, $\alpha$ に関す る関数 Пの最小化問題を解くことにより得られる.

$$
\begin{aligned}
\Pi & =\|\{e r r\}\|^{2}=\{e r r\}^{T}\{e r r\} \\
& =\left\|\left\{_{m} \Delta \varepsilon\right\}-[H(\alpha)]\left\{\varepsilon^{*}\right\}\right\|^{2} \\
& =\left(\left\{_{m} \Delta \varepsilon\right\}-[H(\alpha)]\left\{\varepsilon^{*}\right\}\right)^{T}\left(\left\{_{m} \Delta \varepsilon\right\}-[H(\alpha)]\left\{\varepsilon^{*}\right\}\right)
\end{aligned}
$$

ここで\|・\|はベクトルのユークリッドノルムあるい は $L_{2}$ ノルムを表す。．しかし, 式 (9) は板厚パラメ 一タ $\alpha$ に関して非線形であるため, 繰り返し計算が必 要となる. そこで, 以下のように簡便に $\alpha$ の最適近 似值を求める.

通常の計算では，まず，任意の $\alpha_{i}$ に対して弾性応 答マトリックス $[H(\alpha)]$ を求め，測定位置に対応する 行成分からなる部分応答マトリックスを作成する. 次 に，得られた部分応答マトリックスを用いて， $\alpha_{i}$ に 関する推定固有ひずみ $|\bar{\varepsilon}|_{i}$,を求める. 最後に， $|\bar{\varepsilon}|_{i}$ を式 (9)に代入して，評価関数 Пを求める. これを 繰り返し, 逐次近似法などで $\alpha$ の最適近似値 $\alpha_{\text {|p| }}$ を求 める. しかし, 反復計算に際しては，そのつど FEM 解 析を行う必要がある. そこで，予めいくつかの $\alpha_{i}$ に 関して, 応答曲面を作成し, FEM ではなく応答曲面法 によりПを最小にする最適近似值 $\alpha_{m}$ を求める. 得ら れた $\alpha_{\text {lp }}$ から 次式より推定固有ひずみが得られる.

$$
\left\{\varepsilon^{*}\right\}=[H(\hat{\alpha})]^{-}\left\{_{m} \Delta \varepsilon\right\}
$$

この推定固有ひずみを初期条件として弾性 FEM 解析を 1 度実施すれば残留応力が得られる．しかし，応答曲 面は真の評価関数の近似であるから、ここで得られた $\alpha$ の推定值 $\hat{\alpha}$ は真の最確值の近似值となる. この近 似值をもとに推定された残留応力の誤差については次 節で定量的に議論する。

\section{4. 提案手法に基づく解析結果}

\section{1 残留応力の推定}

正解の固有ひずみを負荷したモデル対して，式(7) の関数形を用いて所定の 12 個の $\alpha_{i}$ に対して弾性応 答マトリックスを求め, 各 $\alpha_{l}$ に対する評価関数 $\Pi_{i}$ から応答曲面を最小二乗法により求めた 図6に評価 関数と $\alpha$ に関する応答曲面を示す.

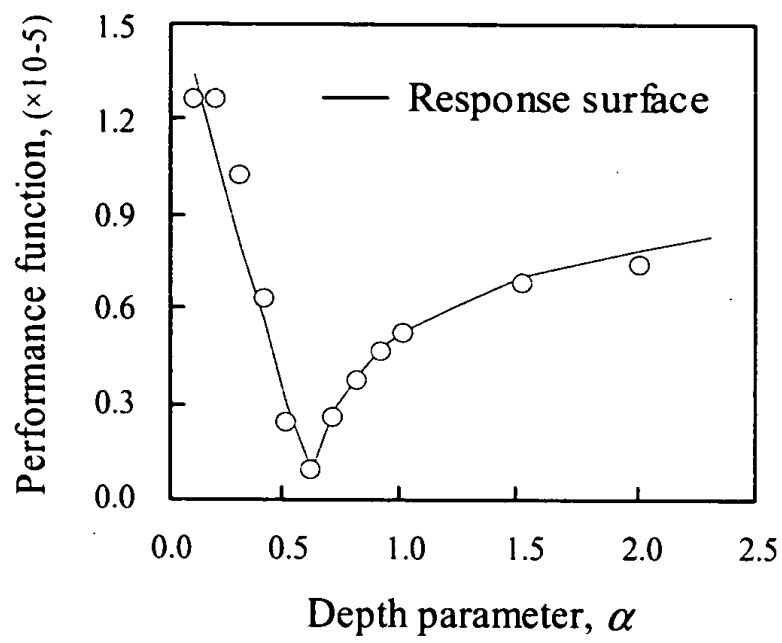

Fig. 6 Response surface of performance function against $\alpha$

弾性解放ひずみの測定誤差を模擬するために，従来 " と同様に標準偏差 $20 \mu$ の正規分布に従う乱数を正解 の弾性解放ひずみに与え，ビードフラッシュ法のシミ ユレーションを行った. 図6の最小近似值 $\alpha_{a p r}=0.6$ から計算される推定残留応力を図 7 に，また比較のた めに式(6) を仮定する従来手法による結果を図8にそ れぞれ示す。

図7の (a) と (b) はそれぞれ部材の表面（余盛り除去 を行った面，最終パス側の面）と蓑面での残留応力分 布であり、シミュレーションは測定誤差の乱数シード のみを変化させて 10 回行った 図 7 から分かるよう に 残留応力の推定分布は表面の板幅力向の残留応力 成分 $\sigma_{y}$ 及び裹測の表面でのビード方向の残留応力成 分 $\sigma_{\mathrm{x}}$ とも，測定誤差のシードに関係なく正解と良い 一致を示している.

一方，固有ひずみ $\left(\begin{array}{lll}\varepsilon_{x} & \varepsilon_{y} & \varepsilon z\end{array}\right)$ の板厚 $(=z)$ 方向 への変化を考慮していない（式 (6) で固有ひずみは $y$ のみの関数である) 図8では 解放ひずみを測定した 表面に関しては，ビードから20mm 離れた位置近㥬を 除けば 正解の分布とほぼ一致しているが，裏面に関 しては正解分布と一致していない，特に，構造健全性 保証に際して重要となる最大引張り応力が正確に評価 されていない．もちろん，溶接条件や板の形状が異な れば，不一致の傾向は異なると考えられるので，厚板 の場合に関しては，固有ひずみの板厚方向への変化を 
考虑する必要があることが分かる．以上の結果より， 本提案手法により表面での解放ひずみの測定から，表 面はもちろん裏面での残留応力も推定が可能なことが 明らかとなった。

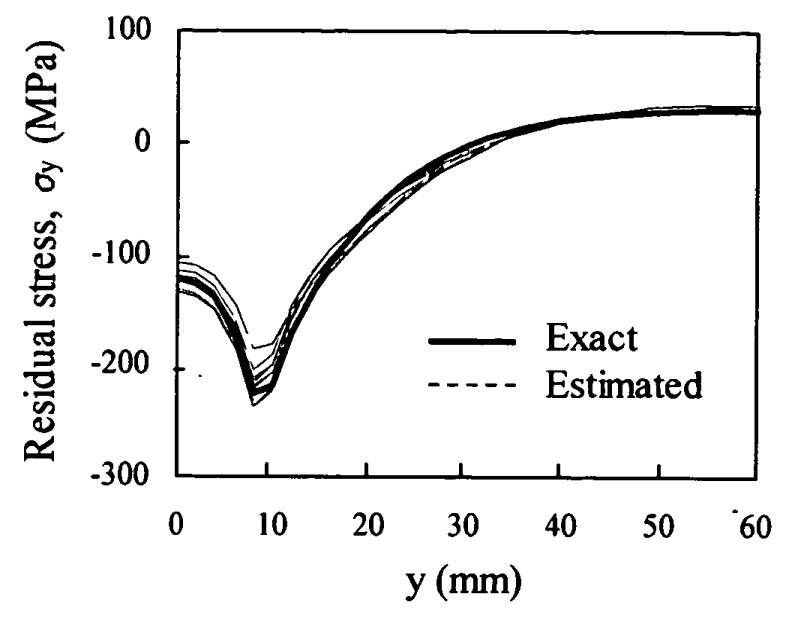

(a) $\sigma_{y}$ at the plate edge of the front surface

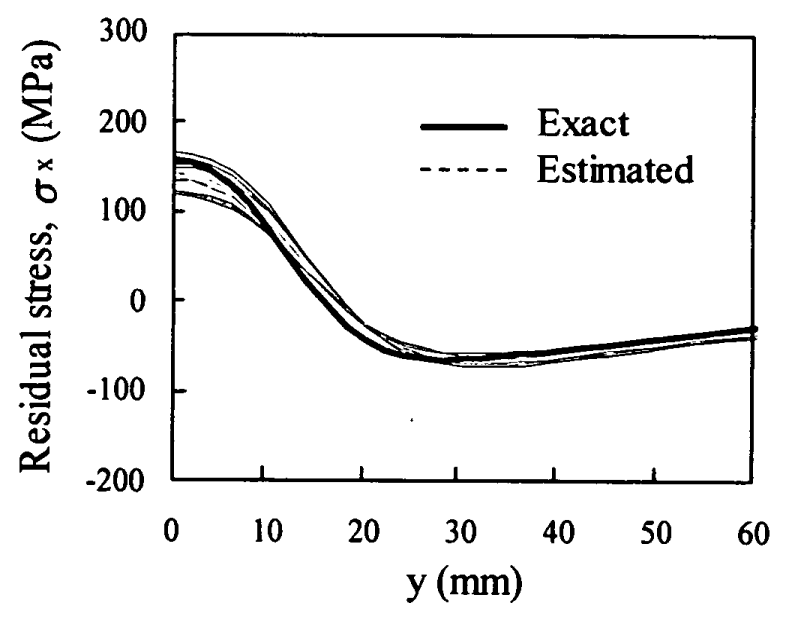

(b) $\sigma_{x}$ at the plate center of the back surface

Fig. 7 Estimated residual stress distribution by the proposed method.

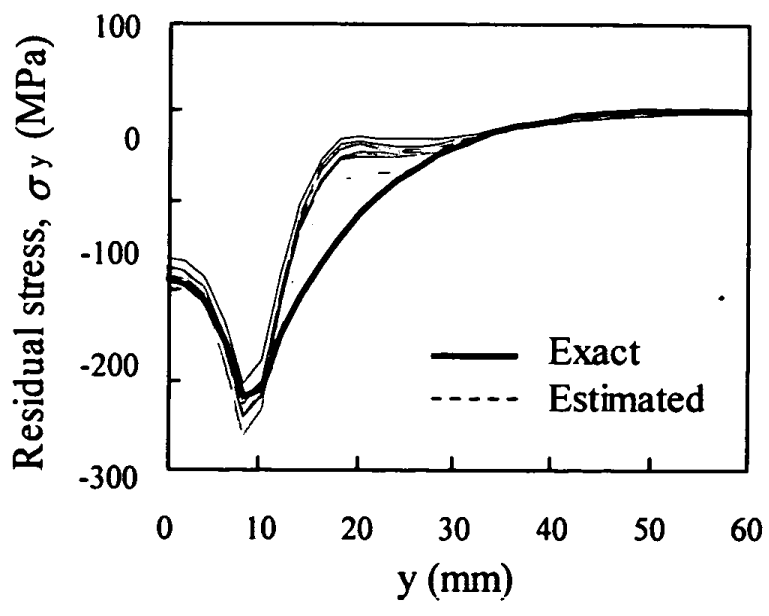

(a) $\sigma_{y}$ at the plate edge of the front surface

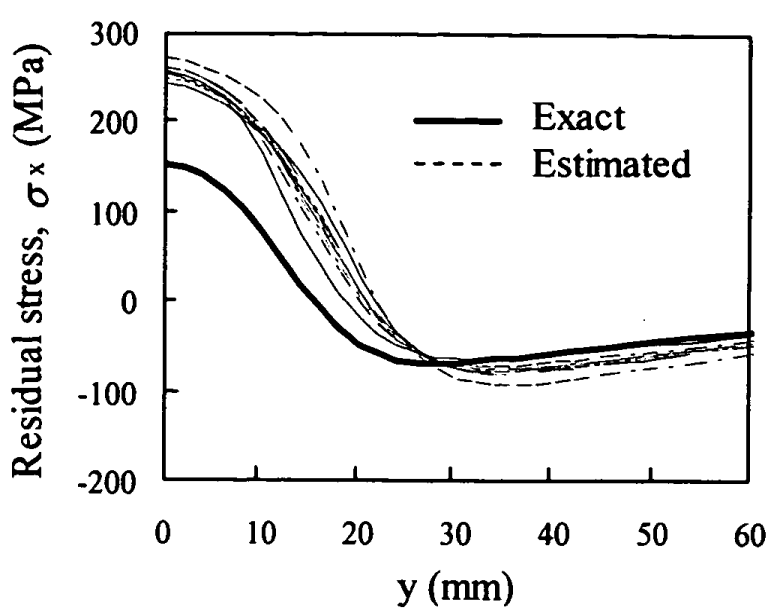

(b) $\sigma_{x}$ at the plate center of the back surface

Fig. 8 Estimated residual stress distribution by the conventional method.

\section{2 推定精度の統計的評価}

応答曲面法によって計算される値は $\alpha$ の近似值で あり,計算される推定残留応力には応答曲面法の導入 による誤差も含むと考えられる.

そこで, 推定精度の統計的な評価を行った. まず, 式(6)と式(7)から残留応力を推定する解析を, 乱数シ 一ドのみを変化させて，150 回繰返す．次に，それぞ れの残留応力分布の推定結果に対して式(11)で定義す る平均推定誤差 $s$ を算出する.

$$
s=\sqrt{\left\{\sum_{c=x, y, z} \sum_{i=1}^{n}\left(\sigma_{c i}-\tilde{\sigma}_{c i}\right)^{2}\right\} / 3 n}
$$

ここで, $\sigma_{c i}$ は $i$ 番要素における推定の残留応力成 分 $(c=x, y, z), \tilde{\sigma}_{a i}$ は $i$ 番要素における正解の残 留応力成分, $n$ は要素総数である. そして, 式(11) の 150 回分の平均值を式(12)で算出する.

$$
S_{m_{i}}=\frac{\sum_{j}^{j=N} s_{j}}{N}
$$

ただし， $N$ は計算試行回数( $(=150)$ である. 前述の図 7 と図 8 は $\alpha$ が約 0.6 の結果であるが， 3.2 節で述へ た正解の固有ひずみ分布を種々に変化させたモデルに ついて，式(6) あるいは式(7) を仮定して逆問題解析 を行い, 式(11)と式(12)から計算される誤差を評価し た.

残留応力の推定誤差の $\alpha$ 依存性を図 9 に示す，ただ し，横軸の $\alpha$ は正解分布を式 (7) で曲線回帰した際 の值である. 式(7)を仮定する解析の場合, 逆解析時 
に応答曲面を用いて $\alpha$ を推定したときに加えて，曲線 回帰から得られる $\alpha$ を予め与えて解析したときの $S_{\text {m }}$ の值（便宜上これを正解值の $S_{z}$ と記述）も比較のた

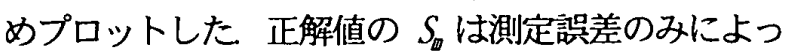
て生じる残留応力の推定誤差を表す量である. この正 解值の $S_{\square}$ と応答曲面を用いて $\alpha$ を推定したときの $S_{\text {m }}$ との差が，応答曲面で評価関数を近似することにより 生じる残留応力の推定誤差 (応答曲面に起因する誤 差）を表している. 図から分かるように，正解値の $S_{\text {I }}$ と式 (6) を仮定する従来手法の差は $\alpha$ が 1 以下で急激 に拡大し, 固有ひずみの厚さ方向への变化を無視して いる効果が顕著に現れている. それに対して，式(れを 仮定する提案手法は正解值の $S_{\varpi}$ とほぼ一致している.

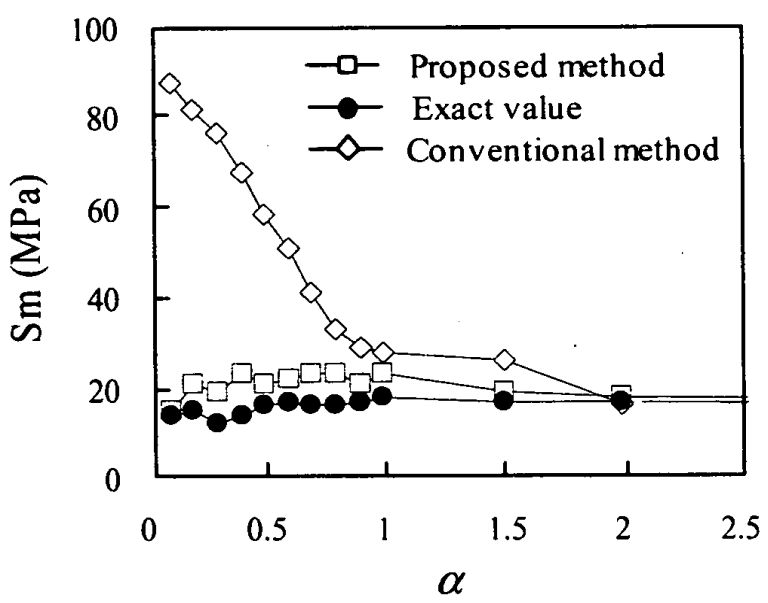

Fig. 9 Effect of $\alpha$ on mean error of residual stresses

以上の結果を総括して，固有ひずみが厚さ方向に 分布する場合には，その影響を考慮して逆問題解析す る必要があり,ここで提案した手法はそのような場合 に対しても，有効に残留応力を推定することができる ことが明らかとなった，なお，式》の有効性に関し ては，今回一種類の溶接条件でしか確認していない. V 型開先の場合には，非線形パラメー夕は 1 個のみで あったが，X 型開先など他の開先形状の場合には，パ ラメータが複数個になる可能性がある. ただし，その ような場合についても，いつたん関数形状が決定でき れば，応答曲面法により，比較的簡便に解が得られる と考えられる. 他方, 未知パラメータの数が増加すれ ば，逆問題解析の解の安定性が損なわれるので，あら たに適切化法などの導入が必要になると考えられる.

したがって, 式(ク)を含めて, ここで提案した手法の 一般的な適用性に関しては，今後さらに溶接条件を変 えた広範囲シミュレーションにより検討する必要があ る.

\section{5. 結 票}

残留応力の非破壊評価手法である，ビードフラッ シュ法の適用性の搪張を目的として，固有ひずみが板 厚方向に分布する場合における新しい解析アルゴリズ 厶を提案し、V 型開先を有する溶接平板を対象とする, 数值シミュレーションによりその有効性を明らかにし た. 得られた結論をまとめれば，以下のようになる.

(1) 固有ひずみが板厚方向に分布する場合，この 効果を考慮していない従来手法では, 残留応 力が正しく評価できない.

（2）そこで，逆問題解析に用いる固有ひずみの関 数形状を, 溶接シミュレーションにより評価 する手法を提案し，厚板の溶接平板について, 具体的にその有効性を示した.

（3）上記の場合，逆問題解析の基礎方程式は非線形 となり, 繰り返し計算のループに有限要素解 析が入るので, 計算量が膨大となる. そこで, 応答曲面法を導入することによりこの解が簡 便に求まることを示した.

\section{文 献}

（1）たとえば，林・ほか 3 名，日本材料学会，Vol. 47, Na. 4 (1998), 420-426

(2) Nakamura H ・ ほか 3 名. Current Topic in Computational Mechanics, ASVE PVP, 305 (1995), 4956

(3) 熊谷・ほか 2 名，機論 (A 偏)，65-629（1999-1）， $133-140$

(4) 熊谷・ほか 2 名, 機論 (A 偏)，65-634（1999-6)， $1397-1404$

(5) Kumagai, K, ・ ほか 2 名, ASTM STP, 1389 (2000), $128-142$

(6) Lee H・ほか 2 名, Symposium on Fatigue, JSUS (2000), 83-86

(7) Lee $\mathrm{H}$ •ほか 2 名, Advances in Fracture and Damage Mechanics II. Hoggar (2001), 283-289

（8）久保司郎，逆問題 (計算力学と CAE シリーズ）培 風館，(1992)，31-33

(9) 上田・麻，溶接学会論文集，11-1（1993），189195

（10）上田・ほか 2 名，溶接学会論文集，11-4（1993）, $555-562$

(11) 上田・麻，溶接学会論文集，12-4（1994），547553

(12) Myers R. H. and Montgomery D. C., "Response Surface Methodology", John Wiley \& Sons Inc, (1995) 